\title{
A New Species of the Genus Garra from Nujiang River Basin, Yunnan, China (Teleostei: Cyprinidae)
}

\author{
CHEN Zi-ming ${ }^{1,3, \#, \text { ZHAO Sheng }}{ }^{2, \#}$, YANG Jun-xing, ${ }^{3, *}$ \\ (1. School of Life Science, Yunnan University, Kunming 650091, China; 2. Yunnan Institute of Environmental Science, Kunming 650034, China;
}

3. Kunming Institute of Zoology, the Chinese Academy of Sciences, Kunming $\quad 650223$, China)

\begin{abstract}
A new species of the subfamily Labeoninae, Garra nujiangensis Chen and Yang, sp. nov. is recognized from a secondary branch of Nujiang River (upper Salween) in Zhenkang county, Yunnan province, China. It can be distinguished from other beardless Garra species by the following combination of characters: $12-14$ circumpeduncle scales; $48-50$ lateral- line scales; a pair of rudimentary rostral barbels present in little individuals; $8-9$ branched dorsal-fin rays; $5-6$ scales between dorsal-fin origin and lateral line and $3-4$ scales between pelvic-fin origin and lateral line; caudal peduncle relatively stouter; length between snout tip to posterior margin of eye longer than body depth at anal fin origin; head length longer than body depth at dorsal fin origin; prepelvic length $50.0 \%-53.7 \%$ of standard length; pre-anus length $58.9 \%-63.9 \%$ of standard length; body width $16.7 \%-19.6 \%$ of standard length; body depth at dorsal fin $19.2 \%-22.6 \%$ of standard length. The present study also verified that the presence of tiny barbells is a juvenile character in some beardless Garra species, such as G. nujiangensis and G. alticorpora.
\end{abstract}

Key words: Garra; Cyprinid; New species; Yunnan

\section{中国怒江流域墨头鱼属鱼类一新种（鲤形目：鲤科）}

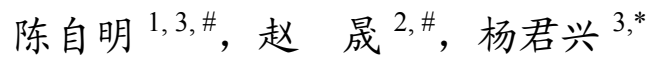 \\ (1. 云南大学 生命科学学院, 昆明 650091；2. 云南省环境科学研究院, 昆明 650034; 3. 中国科学院昆明动物研究所, 昆明 650221)
}

摘要: 2003 年 4 月, 于怒江二级支流镇康县境内的大叉河中采获一批墨头鱼属（Garra）鱼类标本, 经鉴定 为一新种, 命名为怒江墨头鱼 (G. nujiangensis Chen and Yang, sp. nov.)。该新种主要鉴别特征：围尾柄鳞 12 14; 侧线鳞 $48 \sim 50$; 在小个体中有一对微小的吻须; 背鯺分支鳍条 $8 \sim 9$; 侧线上鳞 $5 \sim 6$, 侧线下鳞 $3 \sim 4$; 体高 小于头长; 眤鯺起点处的小于眼后至吻端的距离; 腹鯺前长为体长的 $50.0 \% \sim 53.7 \%$; 肛门前长为体长的 $58.9 \%$ $63.9 \%$; 体宽为体长的 $16.7 \% \sim 19.6 \%$; 体高为体长的 $19.2 \% \sim 22.6 \%$ 。本研究证实，在缺须的墨头鱼属的一些物 种中，如高体墨头鱼（G. alticorpora）和怒江墨头鱼（G. nujiangensis），其幼体中往往具有一对很小的吻须。

关键词: 墨头鱼属; 鲤科; 新种; 中国 中图分类号: Q959.4 68; Q 959.468.09

文献标识码: A 文章编号: 0254-5853-(2009)04-0438-07

Species of cyprinid genus Garra (Hamilton, 1822) are elongate, small- to medium-sized, bottom-dwelling fishes usually found in fast flowing waters, where they adhere to the surface of the rocks using the highly modified lower lip which act as a sucker. The genus occurs widely from south China, Borneo and south Asia through Burma, India, the Middle East, Arabian
Peninsula and East Africa to West Africa (Menon, 1964). Hora (1921) first revised the genus and adopted Garra as the generic name. The latest revision (Menon, 1964) recognized 38 species. Getahun (1999) reviewed 17 African Garra species. More than 10 species from Asia were described or revalidated in recent papers (Kottelat, 1998; Kottelat, 2000; Kottelat, 2001a; Rainboth, 1996;

Received date: 2009-05-13; Accepted date: 2009-06-30

收稿日期：2009-05-13; 接受日期：2009-06-30

基金项目: 国家自然科学基金（40601096; 30870291；30730017）；国家重点基础研究发展计划（九七三计划）项目（2003CB415105); 云南大学理 (工) 科校级科研项目 (2008YB004)

*通讯作者 (Corresponding author), E-mail: yangjx@mail.kiz.ac.cn

\#共同第一作者 (Authors contributed equally to the work) 
Vishwanath \& Sarojnalini, 1988; Vishwanath, 1993; Kosygin \& Vishwanath, 1998; Gopi, 2001; Zhang \& Chen, 2002; Kullander \& Fang, 2004). By now, genus Garra may consist of more than 85 described species, among them, 68 species are from Asia (Kullander \& Fang, 2004; Zhang, 2005).

The species of the imberbis complex (or beardless group) are distributed in Burma, South-China and Indo-China (Menon, 1964). The taxonomy of beardless Garra is a little confusing around the Vietnamese border with China (Kottelat, 2001a). This confusion created difficulty in determining accurate species numbers of beardless Garra in China and Vietnam. Presently, the number of beardless Garra species in China, although requiring further study in comparing different populations of river basins named under one specific name, is relatively clear. There are four species and subspecies of beardless Garra occurring in China, namely, G. pingi pingi, G. pingi yiliangensis, G. pingi hainanensis, G. alticorpora (Zhang et al, 2000; Zhu, 1995). Almost all the Chinese authors (e. g., Wu et al, 1977; Chu \& Cui, 1987; 1989; Zhu, 1995; Chen, 1998) used G. pingi as valid specific name, but according to priority law, G. imberba should be valid to substitute $G$. pingi (Kottelat, 1998; Kottelat, 2001a). Subsequent authors (e. g., Kottelat, 1998; Kottelat, 2001a; Zhang \& Chen, 2005) elevated all the three subspecies as valid species. There are four beardless Garra species in China altogether, G. imberba, G. yiliangensis, G. hainanensis and G. alticorpora. In April 2003, the authors collected beardless specimens of genus Garra representing an undescribed species, from a secondary branch of Nujiang River (upper Salween) in Zhenkang County bordered by Burma, of Yunnan province, China. We herein provide a description of the new species and compare it to other beardless Garra species.

\section{Materials and Methods}

\subsection{Methods}

Measurements were taken point to point with digital calipers measuring to $0.01 \mathrm{~mm}$, and data are recorded to nearest $0.1 \mathrm{~m}$. All counts and measurements were taken following Chu \& Chen (1989). Measurements of disc width, disc length, predorsal, prepectoral, prepelvic and preanal length were taken following Kottelat (2001) and Zhang et al (2002).

The described specimens are formalin-preserved. Abbreviations are listed as following: LP-P, horizontal length between origins of pectoral fin and pelvic fin;
LP-A, horizontal length between origins of pelvic fin and anal fin; LP-AN, Horizontal length between pelvic origin and anus; LS-E, length between snout tip to posterior margin of eye; $\mathrm{AO}$, anal fin origin; $\mathrm{CPL}$, caudal peduncle length; CPD, Caudal peduncle depth; DO, dorsal fin origin; LLS, lateral line scales; D-LL, scales between dorsal-fin origin and lateral line; V-LL, scales between pelvic-fin origin and lateral line; SL, standard length; TL, total length; HL, head length; UCL, upper caudal-fin lobe; MCR, middle caudal-fin rays; LCL, lower caudal-fin lob; DB, dorsal-fin base.

\subsection{Materials examined}

1.2.1 Garra nujiangensis sp. nov. Twelve specimens including one holotype, 9 paratypes and two juvenile non-types listed as following:

Holotype: KIZ200304184, 183.9mm SL; Dachahe River, Altitude: $893 \mathrm{~m}$, Locality: N: $23^{\circ} 57.824^{\prime}$ E: 98 54.337', Fengwei Town of Zhenkang County, Yunnan, China.

Paratype: KIZ200304184, 183.9 mm SL; KIZ200304197, 154.3 mm SL; KIZ200304202, 106.2 mm SL; KIZ200304186, 94.2 mm SL; KIZ200304179, $106.4 \mathrm{~mm}$ SL; KIZ200304196, $112.3 \mathrm{~mm} \quad$ SL; KIZ200304189, 98.9 mm SL; KIZ200304187, $99.2 \mathrm{~mm}$ SL; KIZ200304190, 83.9mm SL; KIZ200304199, 81.6 mm SL; Dachahe River, Altitude: 893m, Locality: N: $23^{\circ} 57.824^{\prime}$ E: $98^{\circ} 54.337^{\prime}$, Fengwei Town of Zhenkang County, Yunnan, China.

Non-type: KIZ200304185, $37.0 \mathrm{~mm}$ SL (with one pair of rudimentary rostral barbels); KIZ200304181, 48.4 mm SL; Dachahe River, Altitude: 893m, Locality: N: $23^{\circ} 57.824^{\prime}$ E: $98^{\circ} 54.337^{\prime}$, Fengwei Town of Zhenkang County, Yunnan, China.

1.2.2 G. alticorpora. 4 specimens. KIZ8540266, 167.7 mm SL; KIZ8540265, 168.2mm SL; KIZ8540276, 50.7 $\mathrm{mm}$ SL (with 2 pairs of rudimentary barbells); KIZ8540202, 53.6mm SL (with 2 pairs of rudimentary barbells); Pingbian County, Yunnan, China.

1.2.3 G. yiliangensis. 6 specimens. KIZ8811402, 181.7 mm SL; KIZ8811401, 180.8mm SL; KIZ8811399, 224.6 mm SL; KIZ8811398, 203.2mm SL; two specimens with blurred catalogs, $167.3 \mathrm{~mm} \mathrm{SL}$ and $153.8 \mathrm{~mm} \mathrm{SL}$ respectively; Guanling County, Guizhou, China.

1.2.4 G. imberba. 6 specimens. KIZ82110103, 199.8 mm SL; KIZ110107, 187.4mm SL; KIZ110096, 171.0 mm SL; KIZ110102, 147.9mm SL; KIZ110099, 194.1 $\mathrm{mm} \mathrm{SL}$; one specimen with no catalog, $78.0 \mathrm{~mm} \mathrm{SL}$; Suijiang County, Yunnan, China.

All specimens examined belong to the collection of 
Kunming Institute of Zoology (KIZ), the Chinese Academic of Sciences.

\section{Results}

Garra nujiangensis Chen and Yang, sp. nov. (Fig.
1).

\subsection{Diagnosis}

This new species can be distinguished from other beardless Garra species by the unique combination of the following features: $12-14$ circumpeduncle scales;

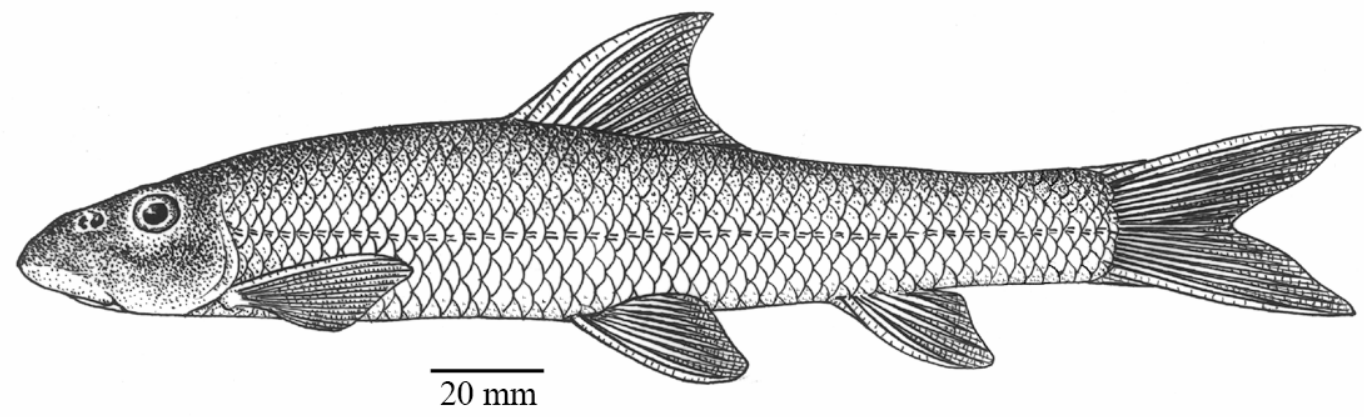

Fig. 1 Garra nujiangensis sp. nov., Holotype KIZ200304184, Zhenkang, Yunnan, China

48 - 50 LLS; D-LL: 5 - 6, V-LL: 3 - 4; a pair of rudimentary rostral barbels present in little indivuaduals; $8^{1} / 2-9 \frac{1}{2}$ branched dorsal-fin rays; caudal peduncle relatively stouter; length between snout tip to posterior margin of eye longer than body depth at anal fin origin; head length longer than body depth at dorsal fin origin; prepelvic length $50.0 \%-53.7 \%$ of standard length; pre-anus length $58.9 \%-63.9 \%$ of standard length; body width $16.7 \%-19.6 \%$ of standard length; body depth at dorsal fin $19.2 \%-22.6 \%$ of standard length.

\subsection{Description}

Counts and proportional measurements are shown in Tab. 1 and Tab. 2.

Body elongate; slightly cylindrical anteriorly and compressed posteriorly; dosal profile slightly convex and ventral surface flattened on head, chest and belly. Head small, depressed with a slightly convex interorbital space. Orbit in the middle-posterior part of head length. Snout round, without transverse groove and having a furrow extending obliquely to lateral extremity of rostral fold; without lateral rostral lobes. Numerous fine tubercles along base of snout before noses. No independent upper lip separating from upper jaw. No barbells present, but a pair of rudimentary rostral barbells present in one small specimen (KIZ200304185, $37.0 \mathrm{~mm} \mathrm{SL}$ ), all the other larger ones without barbells (including a little larger one of $48.5 \mathrm{~mm} \mathrm{SL}$ ). Mental adhesive disc in lower lip elliptical, slightly wider than long. Rostral fold coarsely crenulated, with indentations on its distal margin, covered by numerous papillae. Predorsal mid-line scales reduced and embedded beneath skin. Scales on breast and belly embedded beneath skin. Circumpedunclar scale rows $12-14$, and 4 specimens with 14 scales, 6 specimens with 12 scales. Pharyngeal teeth triserial, $2 \cdot 4 \cdot 5-5 \cdot 4 \cdot 2$.

Dorsal fin inserted anterior to pelvic fin, dorsal fin with a concave distal margin, last simple ray about equal to head length, origin about halfway between snout tip and caudal fin base. Pectoral fin rhomb-shaped, reaching beyond halfway to pelvic-fin origin. Pelvic fin rhomb-shaped, reaching beyond midway to anal-fin origin, inserted vertically below base of $2-3 \mathrm{~h}$ branched dorsal-fin rays. Pelvic fin with an elongate auxiliary scale at its outer base. Auxiliary scale long, reaching beyond base of the last ray. Anal fin with a distally truncate margin. Anus located much nearer to pelvic fin origin than to anal fin origin. Caudal fin forked, lobs about equally long.

Coloration-body, head dark brown to black, small individuals fading slightly, body flank with $4-5$ fain, indistinct, longitudinal stripes. Belly white in live specimens, slightly brown pale in preserved ones. Dorsal and caudal fins gray; dorsal faces of pectoral and pelvic fins gray, ventral faces whitish; anal fin hyaline.

\subsection{Habitat description and propagation time}

This species was collected from shallow water along the bank of the main course and the branches (altitude: $893-909 \mathrm{~m}$ ) of Nanpenghe River (which flows into the Fengwei River, then Nanting River, and finally Salween River in Burma) beside Fengwei Town of Zhenkang County, Yunnan Province. The water is a little turbid black resulted from the wastewater discharged from a sugar refinery. Water temperature was $19.7^{\circ} \mathrm{C}$, and $\mathrm{pH}$ was 8.17 (9:20 AM). The river bed is full of large boulders, cobbles, gravel and little sand. The wet rocks are covered with many diatoms. The propagation 
time is around April to May from the observation that the ovary is at stage IV and the abdomen is filled with large eggs in all the female individuals. Related species: Barbodes baoshanensis, Scaphiodonichthys acanthopterus, Carassius carassius auratus, Schistura fasciolatus, Schistura vinciguerrae, Glyptothorax zainaensis, Pseudecheneis sulcatus, Channa gachua, Bagarius yarrelli.

\subsection{Distribution}

Tab. 1 Proportional measurements comparisons among G. nujiangensis sp. nov., G. theunensis, G. alticorpora, G. yiliangensis and G. imberba

\begin{tabular}{|c|c|c|c|c|c|}
\hline Species & G. nujiangensis & G. theunensis* & G. alticorpora & G. yiliangensis & G. imberba \\
\hline Number of individuals & 10 & 5 & 4 & 6 & 6 \\
\hline Total length & $106.8-246.5$ & - & $66.4-224.2$ & $196.5-271.4$ & $104.1-266.7$ \\
\hline Standard length & $81.6-183.9(112.1)$ & $102.9-175(136.5)$ & $50.7-168.2(110.0)$ & $165.7-203.2(175.4)$ & $78.0-199.8(163.0)$ \\
\hline \multicolumn{6}{|l|}{ Percentage of SL } \\
\hline Head length & $21.7-24.7(23.1 ; 0.8)$ & $23.5-25.9(24.7 ; 1.0)$ & $22.2-25.3(24.5 ; 1.5)$ & $20.8-23.7(22.1 ; 0.9)$ & $21.9-26.1(23.3 ; 1.6)$ \\
\hline Predorsal length & $45.5-50.2(47.9 ; 1.6)$ & $44.7-49.1(46.7 ; 2.0)$ & $46.2-48.7(47.7 ; 1.1)$ & 42.2 - $46.2(44.9 ; 1.6)$ & $46.2-49.1(47.3 ; 1.2)$ \\
\hline Prepelvic length & $50.0-53.7(52.1 ; 1.1)$ & $48.4-50.0(49.4 ; 0.7)$ & $53.1-56.1(54.4 ; 1.5)$ & $47.4-49.3(48.5 ; 0.9)$ & $50.9-54.7(52.2 ; 1.5)$ \\
\hline Pre-anus length & $58.9-63.9(60.9 ; 1.4)$ & $54.2-57.8(56.1 ; 1.4)$ & $60.8-63.5(62.0 ; 1.3)$ & $55.4-57.7(56.7 ; 0.7)$ & $57.5-62.8(59.2 ; 2.0)$ \\
\hline Preanal length & $74.8-79.7(77.7 ; 1.7)$ & $73.3-78.1(76.5 ; 1.9)$ & $77.3-79.1(78.4 ; 0.8)$ & $75.2-78.1(76.4 ; 1.0)$ & $75.7-80.1(77.4 ; 1.7)$ \\
\hline Body width & $16.7-19.6(17.8 ; 1.0)$ & $12.5-16.2(13.9 ; 1.5)$ & $15.9-21.5(19.5 ; 2.6)$ & $14.4-17.3(16.0 ; 1.1)$ & $16.3-19.7(17.2 ; 1.3)$ \\
\hline Body depth at DO & $19.2-22.6(21.4 ; 1.2)$ & $16.1-18.7(17.6 ; 1.0)$ & $22.6-26.0(24.0 ; 1.4)$ & $17.8-20.0(18.9 ; 1.0)$ & $19.1-21.3(20.4 ; 0.9)$ \\
\hline Caudal peduncle length & $14.1-17.4(16.1 ; 1.1)$ & $17.5-19.3(18.1 ; 0.7)$ & $12.1-14.0(13.3 ; 0.8)$ & $15.6-18.0(16.8 ; 0.9)$ & $14.8-16.9(15.9 ; 0.8)$ \\
\hline Caudal peduncle depth & $10.5-11.5(11.0 ; 0.4)$ & $8.3-9.6(8.9 ; 0.6)$ & $11.1-13.1(11.9 ; 0.8)$ & $9.2-10.5(9.9 ; 0.6)$ & $11.5-12.0(11.7 ; 0.2)$ \\
\hline Length of DB & $15.1-18.4(16.6 ; 1.0)$ & $14.2-15.4(15.0 ; 0.5)$ & $15.7-18.6(16.7 ; 1.3)$ & $13.4-17.1(15.6 ; 1.4)$ & $15.7-17.3(16.4 ; 0.7)$ \\
\hline Length of dorsal fin & $20.4-24.9(22.8 ; 1.3)$ & $20.9-30.0(24.5 ; 3.7)$ & $22.8-25.4(23.7 ; 1.2)$ & $22.5-25.4(24.2 ; 1.1)$ & $25.1-27.0(25.7 ; 0.7)$ \\
\hline Length of anal fin & $16.2-19.7(18.1 ; 1.0)$ & $15.8-19.5(17.5 ; 1.6)$ & $17.9-19.4(18.7 ; 0.7)$ & $17.4-19.9(18.7 ; 1.1)$ & $19.3-21.0(20.1 ; 0.6)$ \\
\hline Length of pectoral fin & $17.6-24.5(21.8 ; 1.9)$ & $18.2-19.6(18.8 ; 0.6)$ & $19.9-22.4(21.1 ; 1.4)$ & 19.6 - $22.3(20.9 ; 0.9)$ & $20.4-23.2(21.4 ; 1.1)$ \\
\hline Length of pelvic fin & $17.8-21.2(19.5 ; 1.1)$ & $16.3-18.1(17.7 ; 0.8)$ & $18.9-19.5(19.2 ; 0.3)$ & $19.5-22.4(20.4 ; 1.0)$ & $19.8-21.2(20.4 ; 0.6)$ \\
\hline Length of UCL & $23.2-27.1(24.9 ; 1.2)$ & $25.6-31.1(28.6 ; 2.0)$ & $24.7-26.9(25.9 ; 1.0)$ & $25.1-29.9(27.9 ; 1.8)$ & $28.4-29.5(28.8 ; 0.4)$ \\
\hline Length of MCR & $8.5-15.1(10.6 ; 1.8)$ & $12.2-14.0(12.9 ; 0.7)$ & $9.9-12.8(11.0 ; 1.2)$ & $9.0-12.2(10.3 ; 1.0)$ & $9.4-12.1(10.5 ; 1.0)$ \\
\hline Length of LCL & $23.1-26.6(24.7 ; 1.3)$ & $25.1-30.7(28.1 ; 2.7)$ & $23.9-29.3(27.3 ; 2.6)$ & $27.2-33.1(29.9 ; 2.2)$ & $29.4-31.0(30.0 ; 0.6)$ \\
\hline \multicolumn{6}{|l|}{ Percentage of HL } \\
\hline Snout length & $49.5-59.7(55.0 ; 2.8)$ & $57.0-61.0(58.8 ; 1.6)$ & $50.1-57.2(54.1 ; 3.1)$ & $55.8-59.3(57.5 ; 1.4)$ & $52.2-62.3(58.5 ; 4.2)$ \\
\hline Body depth at DO & $85.3-99.3(92.8 ; 4.8)$ & $64.4-77.0(71.3 ; 5.4)$ & $90.1-107.7(98.5 ; 8.3)$ & $81.2-91.5(85.5 ; 3.5)$ & $81.6-92.0(87.7 ; 3.8)$ \\
\hline Eye diameter & $18.5-23.6(21.0 ; 1.9)$ & $18.0-21.0(20.0 ; 1.4)$ & $17.3-22.5(20.0 ; 2.8)$ & $17.4-21.0(19.1 ; 1.3)$ & $15.3-23.7(17.7 ; 3.1)$ \\
\hline Interorbital width & $47.8-55.1(51.9 ; 2.0)$ & $40.0-44.0(42.4 ; 1.8)$ & $47.6-55.4(51.3 ; 3.2)$ & $46.6-53.4(50.0 ; 2.6)$ & $49.1-53.9(51.5 ; 2.2)$ \\
\hline Disc width & $50.9-56.4(53.1 ; 1.9)$ & $55.0-60.0(57.4 ; 1.9)$ & $52.2-59.3(55.3 ; 3.4)$ & $56.4-60.0(58.3 ; 1.3)$ & $55.4-64.5(60.4 ; 3.8)$ \\
\hline Disc length & $35.4-39.0(37.5 ; 1.0)$ & $35.0-39.0(36.8 ; 1.5)$ & $38.4-43.0(41.3 ; 2.2)$ & $36.6-40.6(38.3 ; 1.8)$ & $34.1-44.6(40.0 ; 3.5)$ \\
\hline \multicolumn{6}{|l|}{ Percentage of CPL } \\
\hline CPD & $62.2-80.7(68.6 ; 5.6)$ & $46.1-54.9(49.0 ; 3.5)$ & $88.2-93.6(89.3 ; 4.4)$ & $54.8-67.5(59.2 ; 4.8)$ & $69.8-81.1(74.1 ; 4.2)$ \\
\hline \multicolumn{6}{|l|}{ Percentage of disc width } \\
\hline Disc length & $67.0-73.3(70.6 ; 2.1)$ & $60.3-70.9(64.2 ; 4.3)$ & $72.5-78.4(74.8 ; 2.8)$ & $62.4-69.5(65.7 ; 3.1)$ & $55.0-71.3(66.4 ; 6.3)$ \\
\hline \multicolumn{6}{|l|}{ Percent of LP-P } \\
\hline Pectoral fin length & $53.4-81.6(68.3 ; 8.1)$ & - & $59.6-69.4(64.5 ; 4.3)$ & $67.6-81.8(73.5 ; 5.4)$ & $69.5-81.3(73.9 ; 4.3)$ \\
\hline \multicolumn{6}{|l|}{ Percent of LP-A } \\
\hline Pelvic fin length & $66.7-85.9(74.5 ; 6.6)$ & - & $75.4-80.5(77.9 ; 2.5)$ & $66.6-81.4(72.5 ; 5.7)$ & $72.6-84.2(78.4 ; 4.3)$ \\
\hline LP-AN & $29.3-39.3(33.5 ; 2.9)$ & - & $29.4-33.8(32.3 ; 2.0)$ & $23.9-37.7(29.7 ; 5.3)$ & $27.9-33.5(30.4 ; 2.3)$ \\
\hline \multicolumn{6}{|l|}{ Percent of LS-E } \\
\hline Body depth at AO & $80.6-94.9(85.6 ; 3.7)$ & - & $\begin{array}{l}83.7-101.8 \text { (91.3; } \\
8.4)\end{array}$ & ;73.1 - $86.1(79.2 ; 6.2)$ & $83.7-92.7(87.3 ; 5.5)$ \\
\hline
\end{tabular}

*From Kottelat (1998).

The first number is mean value in parentheses, and the second one is SD (standard deviation).
So far, this species in known in the Nanpenghe River beside Fengwei Town of Zhenkang County, Yunnan Province (Fig. 2). It is possible that the species also inhabits other tributaries of the Salween in northern Burma and Lower Nujiang River.

\subsection{Etymology}

The specific name, nujiangensis, refers to its type locality in Nujiang River basin, Yunnan Province, China. 
Tab. 2 Counts comparisons among among G. nujiangensis sp. nov., G. theunensis, G. alticorpora, G. yiliangensis and G. imberba

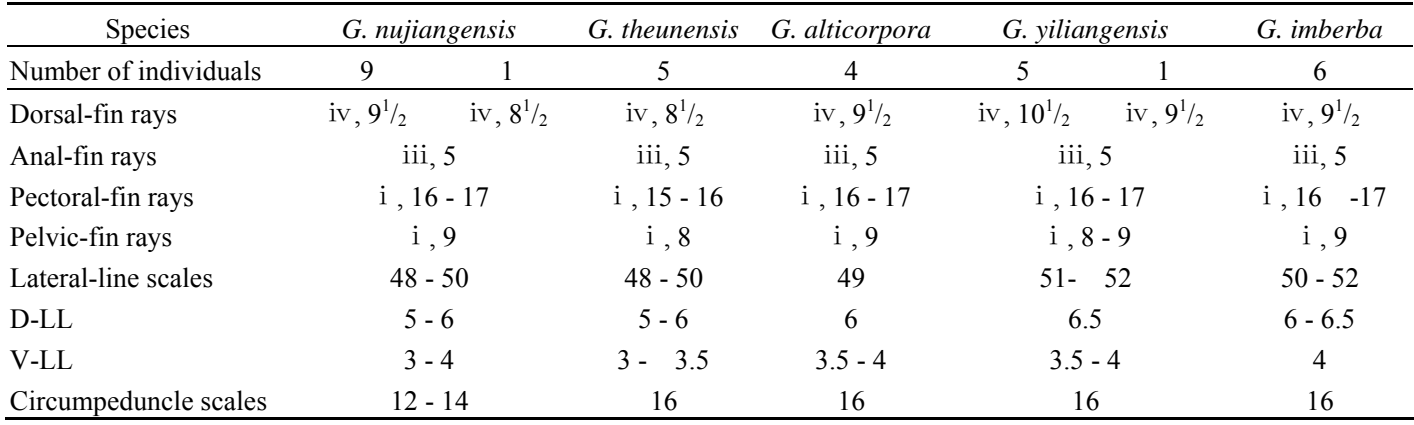

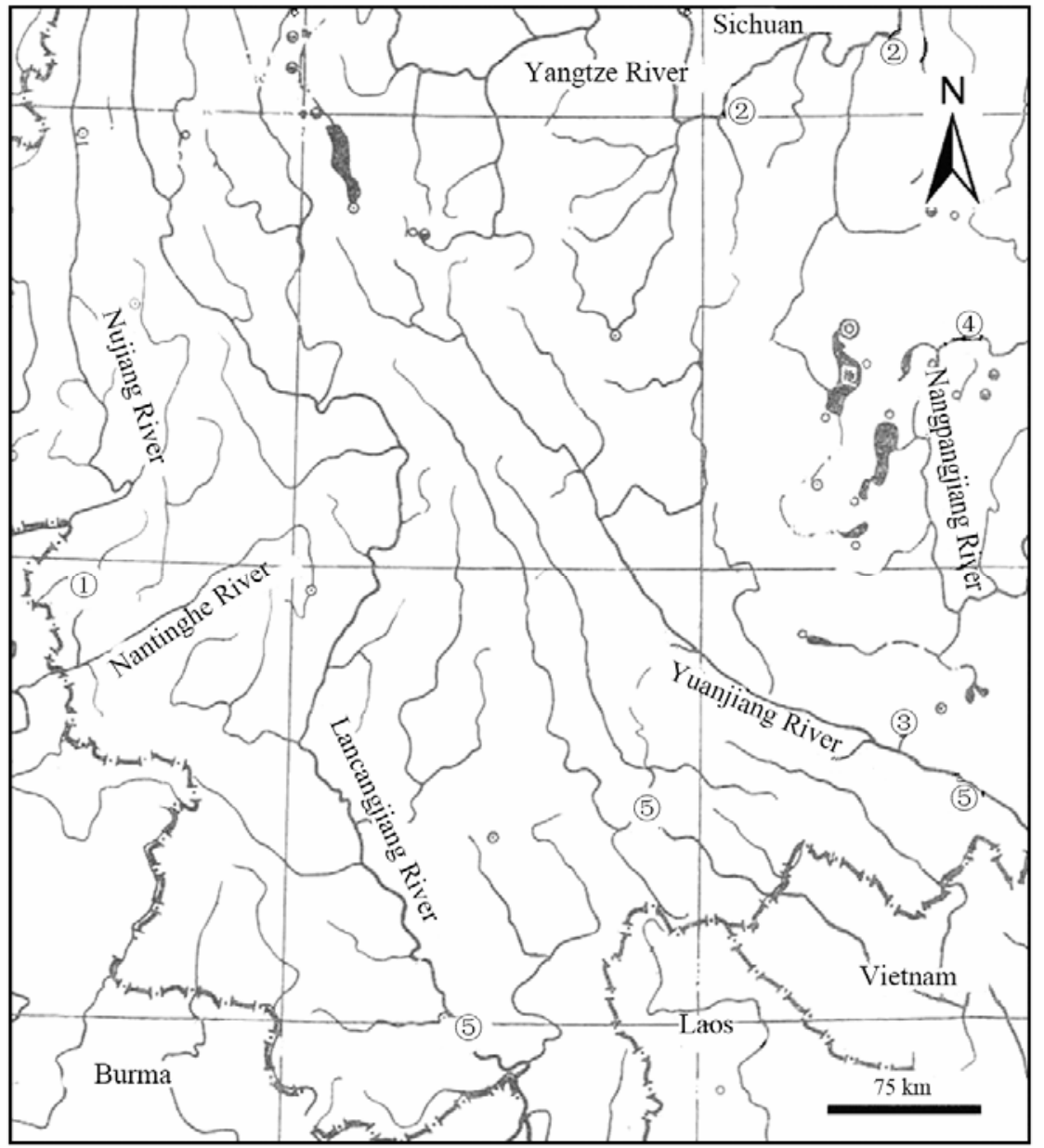

Fig. 2 Map of most portions of Yunnan and partial Sichuan China showing the distributing locality of beardless Garra species in southwest China

(1) Garra nujiangensis sp. nov.; (2) Garra imberba; (3) Garra alticorpora; (4) Garra yiliangensis. (5) the populations of Garra imberba need more and detailed comparisons with each other and other beardless Garra species for confirmation.

\section{Discussion}

Two species of the imberbis complex (or beardless group), which occur in Burma, South-China and Indo-China, are revised by Menon (1964). Presently, the number of beardless Garra species in China has increased to 4 species, namely, G. imberba, G. yiliangensis, G. hainanensis and G. alticorpora. Beardless Garra species have never been recorded in Nujiang River basin (upper Salween). This new species can be distinguished from all the other beardless Garra by the unique character of $12-14$ circumpedunclar 
scales (vs. 16). Additionally, other meristic and proportional characters can also differentiate $G$. nujiangensis from other beardless Garra. G. nujiangensis can be distinguished from $G$. imberba by the combination of the following characters: less LLS (48 - 50 vs. $50-52$ ), less D-LL and V-LL (5- 6 and $3-$ 4 vs. $6-6.5$ and $4-4.5)$, less dorsal fin length (20.4\% $24.9 \%$ SL vs. $25.1 \%-27.0 \%$ SL), less lengths of UCL and LCL $(23.2 \%-27.1 \%$ SL and $23.1 \%-26.6 \%$ SL vs. $28.4 \%-29.5 \%$ SL and $29.4 \%-31.0 \%$ SL), less disc width $(50.9 \%-56.4 \%$ HL vs. $55.4 \%-64.5 \%$ SL). G. nujiangensis can be distinguished from G. alticorpora by the combination of the following characters: less prepelvic length $(50.0 \%-53.7 \%$ SL vs. $53.1 \%-56.1 \%$ SL), less body depth at dorsal fin origin $(19.2 \%-22.6 \%$ SL vs. $22.6 \%-26.0 \%$ SL), greater caudal peduncle length $(14.1 \%-17.4 \%$ SL vs. $12.1 \%-14.0 \%$ SL), less caudal peduncle depth $(10.5 \%-11.5 \%$ SL and $62.2 \%-$ $80.7 \%$ CPL vs. $11.1 \%-13.1 \%$ SL and $88.2 \%-93.6 \%$ CPL), body depth less than body depth at dorsal fin origin (vs. body depth greater than body depth at dorsal fin origin in G. alticorpora, this character may vary in little individuals, as showing in Tab. 3).

Tab. 3 Some meristic and proportional measurements of G. alticorpora

\begin{tabular}{|c|c|c|c|c|c|c|}
\hline Catalog number & KIZ8540266 & KIZ8540265 & KIZ8404276 & KIZ8540202 & Mean value & Standard deviation \\
\hline Total length (mm) & 224.2 & 222.2 & 66.4 & 69.1 & & \\
\hline Standard length $(\mathrm{mm})$ & 167.7 & 168.2 & 50.7 & 53.6 & 110.0 & \\
\hline \multicolumn{7}{|l|}{ Percentage of HL } \\
\hline Body depth at DO & 107.7 & 103.1 & 93.1 & 90.1 & 98.5 & 8.3 \\
\hline \multicolumn{7}{|l|}{ Percent of LS-E } \\
\hline Body depth at AO & $94.5 \%$ & $101.8 \%$ & $85.4 \%$ & $83.7 \%$ & 91.3 & 8.4 \\
\hline Barbels & absent & absent & 2 pairs & 2 pairs & & \\
\hline
\end{tabular}

The new species can be distinguished from $G$. yiliangensis by the following characters: less branched dorsal fin rays $\left(8^{1} / 2-91 / 2\right.$ vs. $10^{1} / 2$ in most individuals as showing in Tab. 2), less LLS and D-LL (48 - 50 and 5 -6 vs. $51-52$ and 6.5$)$, greater prepelvic length (50.0\% - $53.7 \%$ SL vs. $47.4 \%$ - $49.3 \%$ SL), greater pre-anus length $(58.9 \%-63.9 \%$ SL vs. $55.4 \%-57.7 \%$ SL), greater caudal peduncle depth $(10.5 \%-11.5 \% \mathrm{SL}$ and $62.2 \%-80.7 \%$ CPL vs. $9.2 \%-10.5 \%$ SL and $54.8 \%-$ $67.5 \%$ CPL), less length of lower caudal fin lobe (23.1\% - $26.6 \%$ SL vs. $27.2 \%-33.1 \%$ SL), less disc width $50.9 \%-56.4 \%$ HL vs. $56.4 \%-60.0 \%$ SL). It can also be distinguished from $G$. hainanensis by the following characters: $12-14$ circumpedunclar scales (vs. $14-16$ ), 48 - 50 lateral line scales(vs. 46 - 47), less caudal peduncle depth $(62.2 \%-80.7 \%$ CPL vs. $83.3 \%-90.9 \%$ CPL).

Kottelat (1998) described a new beardless Garra, G. theunensis from the Mekong River in Laos. $G$. nujiangensis can be distinguished from this species by the following characters: $12-14$ circumpedunclar scales (vs. 16), greater prepelvic length $(50.0 \%-53.7 \%$ SL vs. $48.4 \%-50.0 \% \mathrm{SL})$, greater pre-anus length $(58.9 \%$ $63.9 \%$ SL vs. $54.2 \%-57.8 \%$ SL), greater body width $(16.7 \%-19.6 \%$ SL vs. $12.5 \%-16.2 \% \mathrm{SL})$, greater body depth at dorsal fin origin $(19.2 \%-22.6 \%$ SL and $85.3 \%$ $-99.3 \%$ HL vs. $16.1 \%-18.7 \%$ SL and $64.4 \%-77.0 \%$
HL), less caudal peduncle length $(14.1 \%-17.4 \%$ SL vs. $17.5 \%-19.3 \% \mathrm{SL})$, greater caudal peduncle depth $(10.5 \%-11.5 \%$ SL and $62.2 \%-80.7 \%$ CPL vs. $8.3 \%-$ 9.6\% SL and $46.1 \%-54.9 \% \mathrm{CPL}$ ).

According to description of G. imberbis (Kullander \& Fang, 2004; Menon, 1964; Talwa \& Jhinggran, 1991.), G. nujiangensis is distinct in having $48-50$ lateral line scales (vs. 44 - 45), in having more transverse scale-rows $(5-6 / 3-4$ vs. $4.5 / 2.5-3)$, in having fine tubercles along base of snout (vs. without tubercles). Compared to questionable G. poilanei, G. cyclostomata (Kottlat, 1998; Kottelat, 2001a), G. nujiangensis can be distinguished by its slender caudal peduncle (CPD 62.2\% - $80.7 \%$ CPL vs. CPD $45.5 \%$ - 55.6\% CPL). G. apogon (Norman, 1925) described from "Ngoi - Tio, Col des Nuages, Tonkin" can be distinguished from $G$. nujiangensis in having $40-42$ "scales in longitudinal series" (vs. $48-50$ ).

The taxonomy of beardless Garra is considerably confusing. This may result from different descriptions based on specimens of different development stages (tiny barbells may be present as juvenile character in some species). Proportional measurement characters may also vary in considerably in individuals of different sizes of the same species, as seen in Tab. 1 and Tab. 3 . Descriptions based on individuals of different trophic conditions, wide distribution in different nations that can 
be described using different methods, descriptions based on limited specimens, no exchange for specimens for comparisons, literatures in different languages (Chinese, English, Vietnamese, Lao and etc) can all influence current species knowledge. The present research verified that tiny barbels is a juvenile character in small specimens of $G$. nujiangensis (less than or equal to $37.0 \mathrm{~mm}$ SL individuals with a pair of barbels), $G$. alticorpora (less than or equal to $69.1 \mathrm{~mm} \mathrm{SL}$ individuals with two pairs of barbells as showing in Tab. 3). This juvenile character may also appear in other beardless Garra species (Kottelat, 2001a).

G. imberba is widely occurring in Yangtze River, Lancangjiang River (upper reach of Mekong), Yuanjiang River (upper reach of Red River) (Chu \& Cui, 1987; Chu \& Cui, 1989; Zhang et al, 2000; Zhu, 1995) in China. Specific status of the three allopatric populations need more detailed comparisons and of complexity beyond the scope of this paper, here we tentatively treat them all as

\section{References:}

Chen YR. 1998. Labeoninae [A]. In: Chen YY (eds.). The Fishes of the Hengduan Mountain Region[M]. Beijing: Science Press, 168-183.

Chu XL, Cui GH. 1987. Taxonomic revision of Chinese cyprinid fishes of the genus Garra Hamilton [J]. Acta Zootax Sin, 12: 93-100. [In Chinese]

Chu XL, Cui GH. 1989. Labeoninae [A]. In: Chu XL, Chen YR (eds). The Fishes of Yunnan, China, Part I[M]. Beijing: Science Press, 229-285.

Getahun A. 1999. Systematic studies of the African species of the genus Garra (Pisces: Cyprinidae) [D]. Ph D thesis. New York: The American Museum of Natural History.

Gopi KC. 2001. Garra periyarensis, a new cyprinid fish from Periyar Tiger Reserve, Kerala, India [J]. J Bombay Nat Hist Soc, 98: 80-83.

Hora SL. 1921. Indian cyprinoid fishes belonging to the genus Garra, with notes on related species from other countries [J]. Rec Indian Mus, 22: 633-687.

Kosygin L, Vishwanath W. 1998. A new cyprinid fish Garra compressus from Manipur, India [J]. J Freshwat Biol, 10: 45-48.

Kottelat M. 1998. Fishes of the Nam Theun and Xe Bangfai basins, Laos, with diagnoses of twenty-two new species (Teleostei: Cyprinidae, Baltoridae, Cobitidae, Coiidae and Odontobutidae) [J]. Ichthyol Explor Freshw, 9: 1-128.

Kottelat M. 2000. Diagnoses of a new genus and 64 new species of fishes form Laos (Teleostei: Cyprinidae, Balitoridae, Bagridae, Syngnathidae, Chauhuriidae and Tetraodontidae) [J]. J South Asian Nat Hist, 5: 37-82.

Kottelat M. 2001a. Freshwater Fishes of Northern Vietnam [M]. Washington: World Bank.

Kottelat M. 2001b. Fishes of Laos [M]. Colombo: Wildlife Heritage Trust Publications.

Kullander SO, Fang F. 2004. Seven new species of Garra (Cyprinidae: Cyprininae) from the Rakhine Yoma, southern Myanmar [J]. Ichthyol Explor Freshw, 15: 257-278.

\section{G. imberba.}

In the Chinese beardless Garra species keys (Chu \& Cui, 1987; Chu \& Cui, 1989; Zhang et al, 2000; Zhu, 1995), two proportional characters, body depth at dorsal fin origin greater than or equal to head length and body depth at anal fin origin equal to length from snout tip to posterior margin of eye, can differentiate G. alticorpora from all the other beardless species. But this does not always work when smaller individuals are included (Tab. 3). Other characters that can distinguish it from related species include a stouter caudal peduncle (CPD 88.2\% 93.6\% CPL), or greater body depth at dorsal fin origin $(22.6 \%-26.0 \% \mathrm{SL})$. Although its relationship with the sympatric populations of $G$. imberba need further study, here we temporally treat it as a valid species and distinct with G. imberba.

Acknowledgments: We thank Mr. WU Bao-lu for preparing the figure of the lateral view of the holotype.

Menon AGK. 1964. Monograph of the cyprinid fishes of the genus Garra Hamilton [J]. Memoir Indian Mus, 14: 173-260.

Norman JR. 1925. Two new fishes from Tonkin, with notes on the siluroid genera Glyptosternum, Exostoma, etc [J]. Ann Mag Nat Hist,: Ser 9, 15: 570-575.

Rainboth W J. 1996. Fishes of the Cambodian Mekong [M]. Rome: FAO.

Talwar PK, Jhinggran AG. 1991. Inland Fishes of India and Adjacent Countries, Volume 1 [M]. New Delhi: Oxford \& IBH Publishing Co.

Vishwanath W, Sarojnalini C. 1988. A new cyprinid fish Garra manipurensis, from Manipur, India [J]. Jpn J Ichthyol, 35(2): 24-126.

Vishwanath W. 1993. On a collection of fishes of the genus Garra Hamilton from Manipur, India, with description of a new species [J]. J freshwat Biol, 5: 59-68.

Wu HW, Lin RD, Chen JX, Chen XL, He MJ. 1977. Barbinae [A]. In: Wu HW (eds). The Cyprinid Fishes of China, Part II[M]. Shanghai: Shanghai People's Press.

Zhang E, Chen YY. 2002. Garra tengchongensis, a new cyprinid species from the upper Irrawaddy River basin in Yunnan, China (Pisces: Teleostei) [J]. Raff Bull Zool, 50 (2): 459-464.

Zhang E. 2005. Phylogenetic relationships of Labeonine cyprinids of the disc-bearing group (Pisces: Teleostei) [J]. Zool Stud, 44 (1): 130-143.

Zhang E. 2005. Garra bispinosa, a new species of cyprinid fish (Teleostei: Cypriniformes) from Yunnan, southwest China [J]. Raff Bull Zool (Supplement), 13: 9-15

Zhang E, Yue PQ, Chen JX. 2000. Labeoninae [A]. In: Yue PQ (eds). Fauna Sinica (Osteichthyes: Cypriniformes III)[M]. Beijing: Science Press.

Zhu SQ. 1995. Synopsis of Freshwater Fishes of China [M]. Nanjing: Jiangsu Science and Technology Press 